\title{
EXPLORING THE IMPACT OF FREE VOLUNTARY READING IN UPGRADING UNIVERSITY STUDENTS' CREATIVE WRITING AT AL BAHA UNIVERSITY
}

\author{
Osama Yousif Ibrahim Abualzain \\ English Department, Al Baha University, Kingdom of Saudi Arabia \\ E-mail: osamaabualzain2011@hotmail.com
}

\begin{abstract}
APA Citation: Abualzain, O. Y. I. (2017). Exploring the impact of free voluntary reading in upgrading university students' creative writing at Al Baha university. English Review: Journal of English Education, 5(2), 189-196
\end{abstract}

Received: 26-04-2017

Accepted: 22-05-2017

Published: 01-06-2017

\begin{abstract}
The purpose of this study is to investigate the impact of free voluntary reading in upgrading university students' creative writing at Al-Baha University. It introduces the types of free voluntary reading that can be employed by the students. In order to achieve this, thirty students at Al-Baha University enrolling in the BA program in English department were chosen randomly. The descriptive analytic method then applied in this study. Pre-test and post-test designed for the students and a questionnaire directed to the teachers were used as tools of collecting data. Finally, the results revealed that free voluntary reading plays critical roles in upgrading the students' creative writing. Also, the teachers highly appreciate the contributions of free voluntary reading materials in pushing forward the students' achievement.
\end{abstract}

Keywords: free voluntary reading, university students, BA program, creative writing

\section{INTRODUCTION}

Reading comprehension as general is the process of making meaning from text. The goal, therefore, is to have an access of what is described in the text rather than to obtain meaning from isolated words or sentences. It is a complex interaction among automatic and strategic cognitive processes that enables the reader to create a mental representation of the text (Van den Broek \& Espin, 2012).

Reading is the key of knowledge. The history of reading goes back to the invention of writing. Reading is of great significance in human life, therefore, it is the main factor in the acquisition of expertise and knowledge. It is a translation of written symbols into spoken words and the relationship between the written symbol and meaning (Al-Jarf, 2007).

Reading and writing are integrated skills since the two skills occur in most situations mutually. Butler and Turbill (1987) argue that there is a broad consensus exists about the relationship between reading and writing. Most experts agree that reading and writing are similar and equally supportive language processes. In line with this, Shanahan (1980) states that strong readers and writers share many habits and practices indicates that there is a strong relationship between reading and writing, and research supports this premise. Reading and writing are closely connected endeavors for these reasons:

- Reading and writing require related-but distinct-cognitive processes.

- Upper elementary students face similar challenges in reading and writing.

- Writing can support reading.

- Reading can support writing.

- Reading and writing together support learning.

Writing creativity as a productive skill goes through different procedure before it comes into being. These steps let the writer to reach an artistic piece of writing that could be accepted by the reader. According 
to Brown (1994), writing is a process where a writer puts his ideas on paper and transforms his thoughts into words. This is not an easy task, especially for an EFL/ESL writer because he has to write down something based on his knowledge of vocabulary and grammar rules as well as a prior knowledge of the topic. Brown (1994) claims that writing is a two-step process; first, you figure out your meaning, and then you put it into language.

Krashen (1988) thinks that those who do more recreational reading show better development in reading, writing, grammar, and vocabulary. He sees that there is a positive relationship between the amount of free reading done and various aspects of second and foreign language competence.

The question of whether creative writing can be assessed or not is a debatable issue. According to Kantor (1972) and Newman (2007), the argument bases on the common misconception that subjective criteria are the only source of estimating creativity in a piece of writing. Similarly, Mackey \& Gass (2005) as cited in Newman (2007, p. 52) think that "the evaluation of works of art is purely subjective and thus cannot be codified." On the other hand, May (2007) condemns the supposition and argues that to objectify evaluation, teachers should try to set standard criteria for evaluating creative works. In addition, Blomer (2011) argues that rubrics or grading grids are the best ways to ensure objectivity in creativity assessment.

Accordingly, this study attempts to explore the impact of free voluntary reading in upgrading university students' creative writing at Al-Baha University. The term Free Voluntary Reading (FVR) was firstly introduced by the famous American linguist Stephen Krashen in his book, The Power of Reading. It is a type of attractive reading that causes pleasure and enjoyment. According to Day and Bamford (2002), both Free Voluntary Reading (FVR) and Extensive Reading (ER) share the same characteristics in developing good reading habits, building up knowledge of vocabulary and structure, and encouraging reading for pleasure.

Krashen (1993) introduced Sustained Silent Reading (SSR) and Self-selected Reading (SR) to assist the in-school FVR program. According to Bader, Veatch, \& Eldridge (1987), Elley (1991), and Jenkins (1957), several studies supported that students in the FVR program outperformed in the reading comprehension tests than ones in traditional skill-based reading instruction. In order to best understand the creative writing process, it is important to define creativity. The word creativity in English comes from the Latin "creatus" which literally means to have grown. To be creative means having the ability or the power to create. Webster's New Collegiate Dictionary (2009) describes creativity as "the ability to create inventions, produce works of art, or solve problems using an original, novel, or unconventional approach." Creativity, therefore, is strongly connected to the verb 'create', which implies creation of any things or thoughts or acts.

Bastrukmen and Lewis (2002) assert that the perception of success in creative writing is associated with self-expressions, the flow of ideas, outsider expectations, growing confidence, and enjoyment of academic writing. They believe that good writing involves the ability to express ideas clearly and confidently to readers. Also, they stress that creative writing enables the students to express themselves more efficiently and with great confidence.

Therefore, this study highlights the three following research questions:

- Is there a relationship between FVR and creative writing?

- Do the students need to improve their writing abilities through reading?

- What are the teachers' point of view?

The implication of the study will have a great value to the students who want to improve their writing skills and go further into creative writing. To achieve this, the 
students have to go through free voluntary reading process. For syllabus designers, they have to choose best attractive reading materials that face the needs and the interests of the students.

\section{METHOD}

Thirty male students at Al-Baha University enrolling in the BA program in English department were chosen randomly as the participants of this study. The students specialize in English language and literature. The students' age ranged from 19 to 21 years old and they have been learning English for ten years. This study was conducted in February 2017. Questionnaire and tests were employed to collect data for the study.

\section{Teachers' Questionnaire}

To make authentic and reliable data, it is incumbent to introduce the English teachers' point of view. The feedback of the English teachers is highly recommended in this type of study. According to Oxford \& Leaver (1996), questionnaires can give general assessments. They are effective, quick, and easy to administer and don't threaten the respondents. Generally, through the questionnaire, the English teachers were asked whether the FVR helps pushing forward writing creativity among students or not. The questionnaire used in this study is shown below.

Table 1. Teachers' Questionnaire

\begin{tabular}{|c|c|c|c|c|c|c|}
\hline \multirow{2}{*}{ No. } & \multirow{2}{*}{ Statement } & \multicolumn{5}{|c|}{ Answer } \\
\hline & & SD & D & $\mathbf{N}$ & $\mathbf{A}$ & SA \\
\hline 1. & Students face difficulties in writing as general. & & & & & \\
\hline 2. & $\begin{array}{l}\text { The existing reading materials in the syllabus do not } \\
\text { satisfy the needs of the students. }\end{array}$ & & & & & \\
\hline 3. & FVR develops language proficiency. & & & & & \\
\hline 4. & FVR encourages students to read for pleasure. & & & & & \\
\hline 5. & $\begin{array}{l}\text { There is a close relationship between FVR and creative } \\
\text { writing. }\end{array}$ & & & & & \\
\hline 6. & $\begin{array}{l}\text { FVR introduces students to good models of creative } \\
\text { writing. }\end{array}$ & & & & & \\
\hline 7. & The styles of FVR develop different writing techniques. & & & & & \\
\hline 8. & $\begin{array}{l}\text { FVR materials including fiction develops creative } \\
\text { imagination. }\end{array}$ & & & & & \\
\hline 9. & Attractive reading materials inspire writing creativity. & & & & & \\
\hline 10. & $\begin{array}{l}\text { Exposing students to different types of reading materials } \\
\text { provide background for good writing. }\end{array}$ & & & & & \\
\hline $\begin{array}{l}* \mathrm{SD} s \\
* \mathrm{Dst} \\
* \mathrm{~N} \mathrm{st} \\
* \mathrm{Ast} \\
* \mathrm{SAs}\end{array}$ & $\begin{array}{l}\text { ands for strongly disagree. } \\
\text { nds for disagree. } \\
\text { nds for neutral. } \\
\text { nds for agree. } \\
\text { rongly agree. }\end{array}$ & & & & & \\
\hline
\end{tabular}

\section{Students' Pre and post- writing tests}

Pre and post-writing tests are the same tests. They were administered before and after the treatment of FVR. Specifically, the pre-test took place at the beginning of the semester, while the post-test was held by the end of the semester. During the research, the students were divided into two groups, namely control group and experimental group. The control group does not go under any additional reading practice, whereas the experimental group goes through extra free voluntary reading materials which were chosen by the readers themselves. The aim behinds this procedure is to find out whether there is any significant difference between 
the performances of the two groups. The pre- and post-writing test results were documented in order to compare and analyze the students' performance. By the help of the creative writing rubric, the performance of the two groups is evaluated and measured. The creative writing rubric used in this study is shown in Table 2.

Table 2. Creative Writing Rubric

\begin{tabular}{|c|c|c|c|c|}
\hline Criteria & 4. Excellent & 3. Good & 2. Fair & 1. Poor \\
\hline Image & $\begin{array}{l}\text { Maximal use of } \\
\text { significant details } \\
\text { (there is no or just } \\
1 \text { abstraction, } \\
\text { generalization } \\
\text { and judgment) }\end{array}$ & $\begin{array}{l}\text { Several use of } \\
\text { significant details } \\
\text { (they are } \\
\text { significantly more } \\
\text { than abstractions, } \\
\text { generalizations } \\
\text { and judgments) }\end{array}$ & $\begin{array}{l}\text { Minimal use of } \\
\text { significant details } \\
\text { (they are } \\
\text { significantly less } \\
\text { than abstractions, } \\
\text { generalizations } \\
\text { and judgments) }\end{array}$ & $\begin{array}{l}\text { No use of } \\
\text { significant details } \\
\text { (sole use of } \\
\text { abstractions, } \\
\text { generalizations } \\
\text { and judgments) }\end{array}$ \\
\hline Characterization & $\begin{array}{l}\text { Maximal use of } \\
\text { characters' } \\
\text { physical } \\
\text { appearance, } \\
\text { action, thought, } \\
\text { symbol, etc. to } \\
\text { reveal characters } \\
\text { (complete indirect } \\
\text { characterization) }\end{array}$ & $\begin{array}{l}\text { Several use of } \\
\text { characters' } \\
\text { physical } \\
\text { appearance, } \\
\text { action, thought, } \\
\text { symbol, etc. to } \\
\text { reveal characters }\end{array}$ & $\begin{array}{l}\text { Minimal use of } \\
\text { characters' } \\
\text { physical } \\
\text { appearance, } \\
\text { action, thought, } \\
\text { symbol, etc. to } \\
\text { reveal characters }\end{array}$ & $\begin{array}{l}\text { No use of } \\
\text { characters' } \\
\text { physical } \\
\text { appearance, } \\
\text { action, thought, } \\
\text { symbol, etc. to } \\
\text { reveal characters } \\
\text { (complete direct } \\
\text { characterization) }\end{array}$ \\
\hline Voice & $\begin{array}{l}\text { Maximal use of } \\
\text { images to make } \\
\text { the voice } \\
\text { appealing }\end{array}$ & $\begin{array}{l}\text { Several use of } \\
\text { images to make } \\
\text { the voice } \\
\text { appealing }\end{array}$ & $\begin{array}{l}\text { Minimal use of } \\
\text { images to make } \\
\text { the voice } \\
\text { appealing }\end{array}$ & $\begin{array}{l}\text { No use of images } \\
\text { to make the voice } \\
\text { appealing }\end{array}$ \\
\hline Story & $\begin{array}{l}\text { The use of } \\
\text { narrative to } \\
\text { convey purpose. }\end{array}$ & - & - & $\begin{array}{l}\text { No use of } \\
\text { narrative to } \\
\text { convey purpose } \\
\text { (purpose is } \\
\text { conveyed through } \\
\text { formal statement) }\end{array}$ \\
\hline
\end{tabular}

\section{RESULTS AND DISCUSSION}

The study explored the impact of free voluntary reading in upgrading university students' creative writing at Al-Baha University. As stated previously, questionnaire and tests were used to collect the data needed. Questionnaire was used to know whether or not the FVR helps pushing forward writing creativity among students. While the test was used to see the students' performance before and after the treatment. The analysis of the collected data is shown in the following sub-sections.

\section{Students' pre -test}

The students were given a storytelling which is considered to be one of the most popular types of creative writing in the pre and post-test. Storytelling lends itself to both fiction and nonfiction. Popular forms include flash fiction and short stories. The pre-test was given to both the control and the experimental group before the treatment. The result of the students' pre-test is described below. 
Table 3. The correlations between the students' score on pre-test

\begin{tabular}{|c|c|c|c|c|c|c|}
\hline & & Students' score & excellent & good & fair & poor \\
\hline \multirow{3}{*}{$\begin{array}{l}\text { Students' } \\
\text { score }\end{array}$} & Pearson Correlation & 1 & $-.222-$ & $.509^{* *}$ & $-.309-$ & .076 \\
\hline & Sig. (2-tailed) & & .239 & .004 & .097 & .688 \\
\hline & $\mathrm{N}$ & 30 & 30 & 30 & 30 & 30 \\
\hline \multirow[t]{3}{*}{ excellent } & Pearson Correlation & $-.222-$ & 1 & $-.362^{*}$ & $-.106-$ & -.189 \\
\hline & Sig. (2-tailed) & .239 & & .049 & .576 & .318 \\
\hline & $\mathrm{N}$ & 30 & 30 & 30 & 30 & 30 \\
\hline \multirow[t]{3}{*}{ good } & Pearson Correlation & $.509^{* *}$ & $-.362^{*}$ & 1 & $-.372^{*}$ & $-.144-$ \\
\hline & Sig. (2-tailed) & .004 & .049 & & .043 & .447 \\
\hline & $\mathrm{N}$ & 30 & 30 & 30 & 30 & 30 \\
\hline \multirow[t]{3}{*}{ fair } & Pearson Correlation & $-.309-$ & $-.106-$ & $-.372^{*}$ & 1 & $-.731^{* * *}$ \\
\hline & Sig. (2-tailed) & .097 & .576 & .043 & & .000 \\
\hline & $\mathrm{N}$ & 30 & 30 & 30 & 30 & 30 \\
\hline \multirow[t]{3}{*}{ poor } & Pearson Correlation & .076 & $-.189-$ & $-.144-$ & $-.731^{* *}$ & 1 \\
\hline & Sig. (2-tailed) & .688 & .318 & .447 & .000 & \\
\hline & $\mathrm{N}$ & 30 & 30 & 30 & 30 & 30 \\
\hline
\end{tabular}

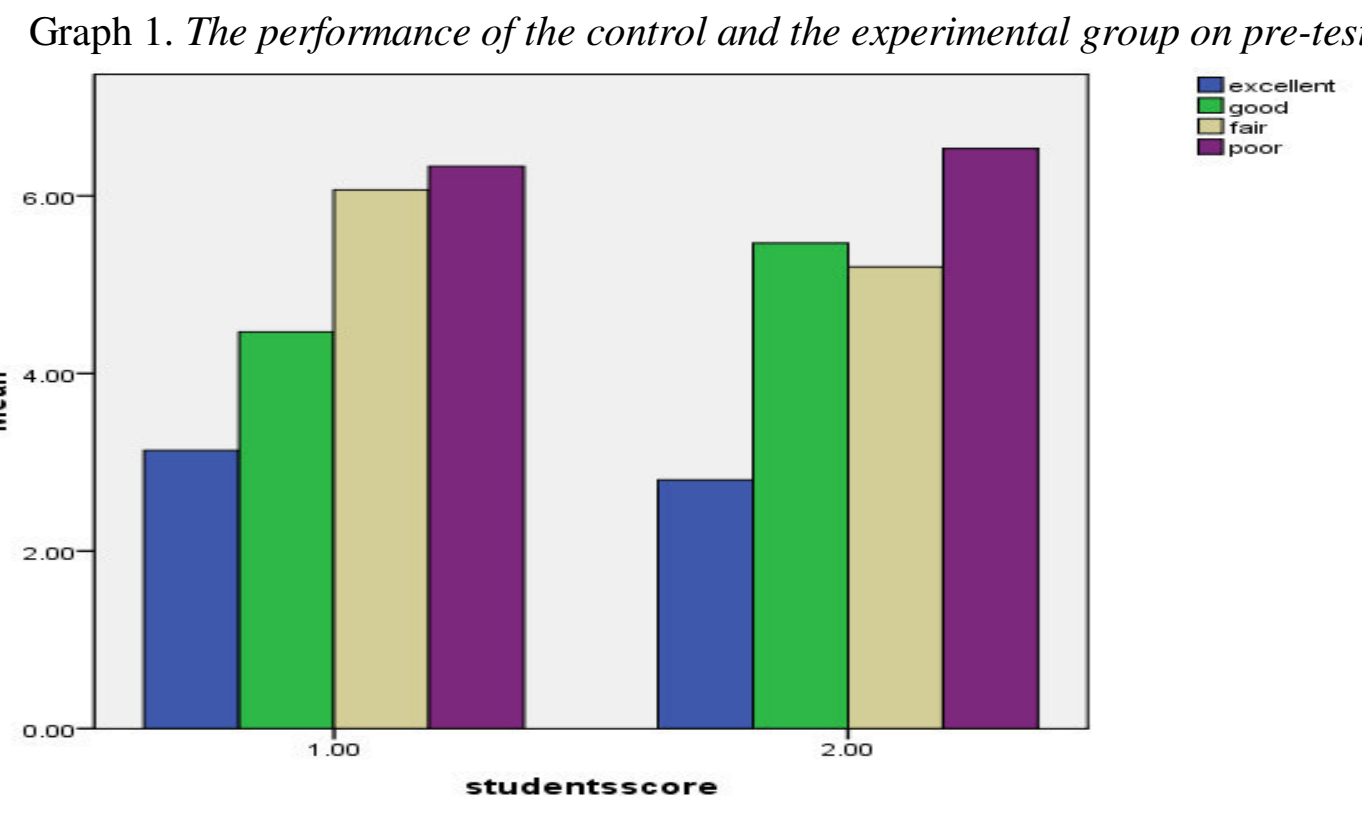

\footnotetext{
*1 stands for the control group

*2 stands for the experimental group
}

From Table 3, we can observe that the correlations between the performance of the students in both control and experimental group is significant (0.01). In addition, Graph 1 introduces and compares the performance of each group. Because the students attend the same classes and experience the same situation, no considerable differences between the achievements of the students appear. 


\section{Students' post-test}

The post-test took place after the experimental group had gone through FVR process whereas the control group enrolled into their normal course. The result of the students' post-test is described below.

Table 4. The correlations between the performance of the students on post-test

\begin{tabular}{|c|c|c|c|c|c|c|}
\hline & & studentsscore & excellent & good & fair & poor \\
\hline \multirow[t]{3}{*}{ studentsscore } & Pearson Correlation & 1 & $.781^{* *}$ & $.675^{* *}$ & $-.271-$ & $-.753^{* *}$ \\
\hline & Sig. (2-tailed) & & .000 & .000 & .148 & .000 \\
\hline & $\mathrm{N}$ & 30 & 30 & 30 & 30 & 30 \\
\hline \multirow[t]{3}{*}{ excellent } & Pearson Correlation & $.781^{* *}$ & 1 & .284 & $-.321-$ & $-.583^{* *}$ \\
\hline & Sig. (2-tailed) & .000 & & .129 & .083 & .001 \\
\hline & $\mathrm{N}$ & 30 & 30 & 30 & 30 & 30 \\
\hline \multirow[t]{3}{*}{ good } & Pearson Correlation & $.675^{* *}$ & .284 & 1 & $-.242-$ & $-.690^{* *}$ \\
\hline & Sig. (2-tailed) & .000 & .129 & & .198 & .000 \\
\hline & $\mathrm{N}$ & 30 & 30 & 30 & 30 & 30 \\
\hline \multirow[t]{3}{*}{ fair } & Pearson Correlation & $-.271-$ & $-.321-$ & $-.242-$ & 1 & $-.262-$ \\
\hline & Sig. (2-tailed) & .148 & .083 & .198 & & .162 \\
\hline & $\mathrm{N}$ & 30 & 30 & 30 & 30 & 30 \\
\hline \multirow[t]{3}{*}{ poor } & Pearson Correlation & $-.753^{* *}$ & $-.583^{* * *}$ & $-.690^{* *}$ & $-.262-$ & 1 \\
\hline & Sig. (2-tailed) & .000 & .001 & .000 & .162 & \\
\hline & $\mathrm{N}$ & 30 & 30 & 30 & 30 & 30 \\
\hline \multicolumn{4}{|c|}{$* *$. Correlation is significant at the 0.01 level (2-tailed). } & & & \\
\hline
\end{tabular}

Graph 2. The performance of the control and the experimental group on post-test

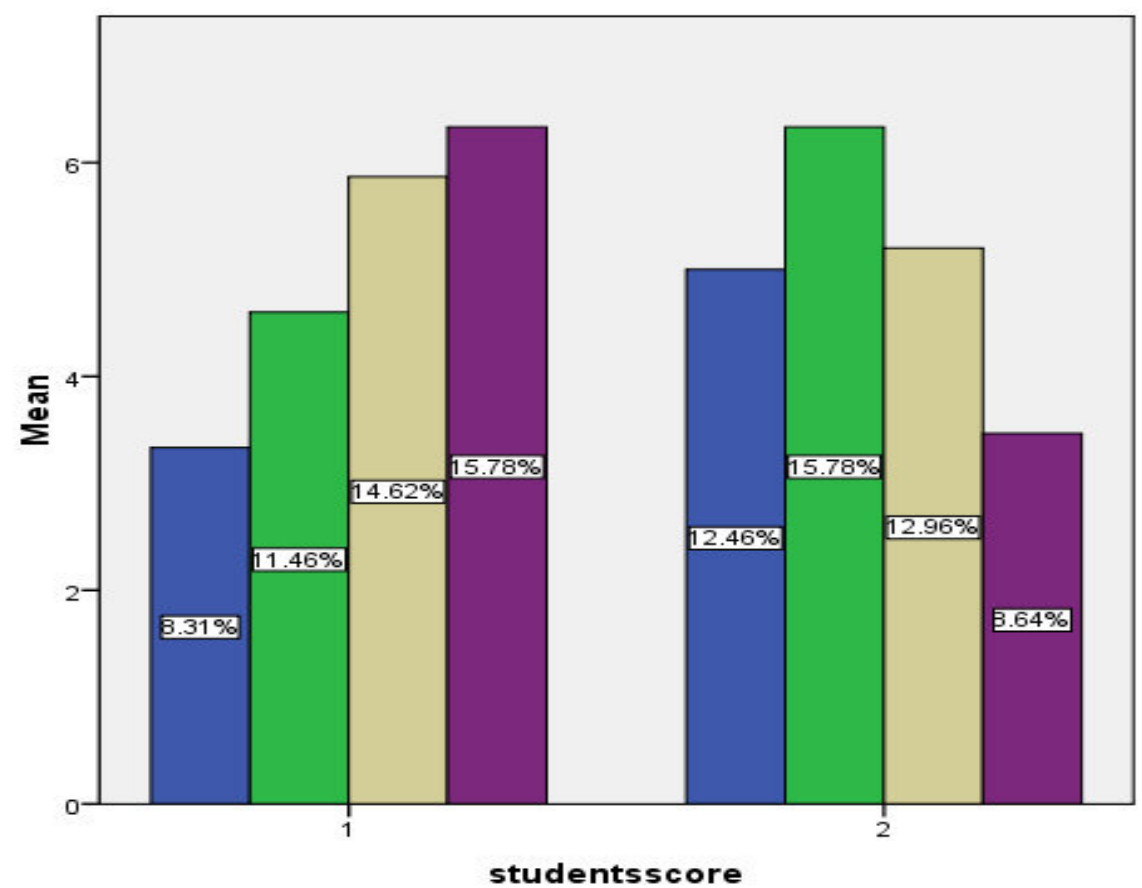


Table 4 and Graph 2 show the performance of the control and the experimental groups on post-test. It shows clearly that the achievement of the students in control group does not reflect a considerable progress and seems to be the same. This is due to the limitations of reading sources which do not give the progress towards the students' abilities in writing as general and creative writing in special case. On the other hand, the experimental group shows obvious improvement in creative writing. On pre-test, only $7.00 \%$ of the students in the experimental group who got excellent score in writing creativity, while the portion rises up to $12.46 \%$ which is considered as a remarkable progress on post-test. Also, $13.67 \%$ of the students got good degree on pre-test, whereas the percentage goes up on post-test and reaches $15.78 \%$. Besides, the students who showed poor performance on pre-test were
$16.33 \%$ whereas a considerable improvement takes place on post-test and the percentage falls down to $8.64 \%$.

\section{Teachers' Questionnaire}

Teachers' questioner is a very important resource and a reliable data. After the process of consulting and piloting of the questionnaire, twenty five English teachers were selected as respondents. The questionnaire consists of ten statements and follows Likert scale which is the most widely used approach to scaling responses in survey research. The format of a typical five-level Likert item, for example, could be:

1. Strongly disagree

2. Disagree

3. Neither agree nor disagree (neutral)

4. Agree

5. Strongly agree

Table 5. Descriptive Statistics of the teachers' questionnaire

\begin{tabular}{cccccc}
\hline & N & \multicolumn{2}{c}{ Mean } & Std. Deviation & Variance \\
\hline & Statistic & Statistic & Std. Error & Statistic & Statistic \\
\hline items & 10 & 5.50 & .957 & 3.028 & 9.167 \\
\hline SD & 10 & 2.60 & .306 & .966 & .933 \\
\hline D & 10 & 3.40 & .340 & 1.075 & 1.156 \\
\hline N & 10 & 3.70 & .423 & 1.337 & 1.789 \\
\hline A & 10 & 8.00 & .447 & 1.414 & 2.000 \\
\hline SA & 10 & 7.30 & .396 & 1.252 & 1.567 \\
\hline
\end{tabular}

Valid N (list wise) $\quad 10$

Graph 3. The teachers' response to the questionnaire

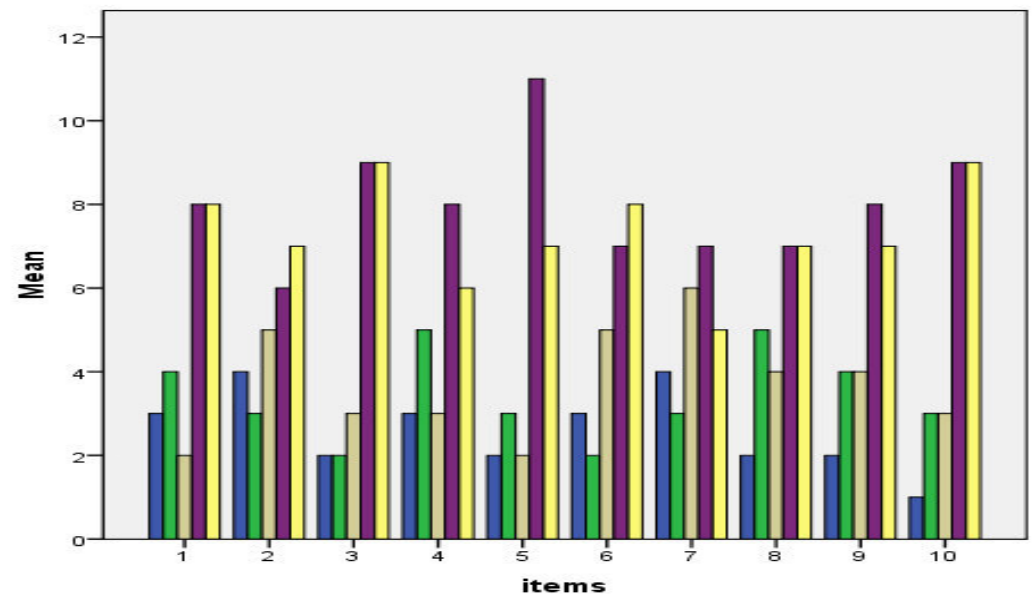


Table 5 and Graph 3 show the responses of the teachers to the questionnaire. The researcher categorizes SA and A as positive responses that support the idea of employing FVR to upgrade the students' performance in creative writing. N's score is neglected, SD and D responses are listed as negative ones. Table 5 shows that the mean of the positive responses is 7.3 for SA and 8.00 for A, while the mean of the negative responses is 2.6 for SD and 3.4 for D. This reveals that the majority of the teachers confirm the importance of FVR in pushing forward creative writing skills among university students.

\section{CONCLUSION}

From the data analysis, it becomes clear that FVR plays a critical role in upgrading students' creative writing at AlBaha university. The findings of this study match the research questions. The research questions in this study are answered clearly and supported by the data analysis. The results show that when the students restore to FVR and choose the reading materials themselves, a remarkable improvement will take place in all language skills especially in writing creativity. The teachers' responses also reveal that there is a close relationship between FVR and creative writing. Here, the teachers confirm the importance of FVR to upgrade the students' creative writing and think that attractive reading materials generate writing creativity in the students' writings. The teachers also criticize the existing reading materials in the syllabus that lack attractiveness to motivate the students and inspire them to write creatively.

\section{REFERENCES}

Al-Jarf, R. (2007). Developing reading and literacy skills in Saudi Arabia. Retrieved from: ksu.edu.sa/jspui/handle/123456789/ 7709.

Bader, L., Veatch, J., \& Eldridge, J. (1987). Trade books or basal readers? Reading Improvement, 24, 62-67.

Bastrukmen, H., \& Lewis, M. (2002). Learner perspectives of success in an EAP writing
Course. Assessing Writing, 8(1), 31-46.

Retrieved from:

http://dx.doi.org/10.1016/S1075-

2935(02)00032-6

Blomer, Y. (2011). Assessment in creative writing. Wascana Review, 43, 61-73.

Brown, H. D. (1994). Principles of language learning and teaching (3rd ed.). Englewood Cliffs, NJ: Prentice Hall Regents.

Butler, A. \& Turbill, J. (1987). Towards a readingwriting classroom. Portsmouth, $\mathrm{NH}$ : Heinemann.

Day, R., \& Bamford, J. (2002). Top ten principles of teaching extensive reading. Reading in a Foreign Language, 14, 136-141.

Elley, W. (1991). Acquiring literacy in a second language: The effect of book-based programs. Language Learning, 41, 375-411.

Jenkins, M. (1957). Self-selection in reading. Reading Teacher, 10, 84-90.

Kantor, K. (1972). Evaluating creative writing: A different ball game. The English Journal, 64, 72-74.

Krashen, S. (1988). Do we learn to read by reading? The relationship between free reading and reading ability (pp. 269- 298). In D. Tannen (Ed.) Linguistics in context: Connecting observation and understanding. Norwood, $\mathrm{NJ}$ : Ablex.

Mackey, A. \& Gass, S. (2005). Second language research. New Jersey: Lawrence Erlbaum Associates.

May, S. (2007). Doing creative writing. New York: Routledge.

Newman, J. (2007). The evaluation of creative writing at M.A. level (UK). In S. Earnshaw (ed.), The handbook of teaching creative writing. Edinburg: Edinburg University Press.

Oxford, R. L., \& Leaver, B. L (1996). A synthesis of strategy instruction for language learners. In R. L. Oxford (ed.), Language learning strategies around the world: Cross cultural perspectives. Manoa: University of Hawaii Press.

Shanahan, T. (1980). The impact of writing instruction on learning to read. Reading World, 19(4), 357-368.

Van den Broek, P., \& Espin, C. A. (2012). Connecting cognitive theory and assessment: Measuring individual differences in reading comprehension. School Psychology Review, 41(3), 315-325.

Webster's New World College Dictionary (4th Ed). (2009). Longman Dictionary of Contemporary English for Advanced Learners. 